interfaces. On the whole, the study of proteins spread as films at interfaces has been disappointing since, as these authors point out, the specific properties are lost when unfolding takes place. The method on the whole has thrown little light on protein specificity or size, but the authors are able to deduce some interesting reactions of drugs and growth regulators.

J. A. V. ButeER

\section{THE ORIGINS OF EDUCATION}

\section{Ancient Education}

By Prof. William A. Smith. Pp. xii +309 . (New York : Philosophical Library, 1955.) 3.75 dollars.

DROF. WILLIAM A. SMITH might well have lost would-be readers by his turgid preface. "Since education is a broad concept," he says, "a concept the connotation of which ranges all the way from the total socialisation process operative in a society to formally organised institutional programs, its scope for historical treatment must of necessity be delimited." There are twelve abstracts in those lines. But his book is, in fact, altogether stimulating. The enormous field he has to cover, in surveying the great civilizations of the ancient world, makes for speed and directness and thereby saves him willy-nilly from overmuch technical jargon. Furthermore, his pages read all the more smoothly for being very systematic. One knows precisely where one is the whole time.

A book on ancient education was long overdue, for the treatment in the standard histories of educa. tion at large has rarely yet been more than merely tantalizing. Nor have all these standard histories been quite clear as to how far 'education' means the same when they are looking at Ancient Sumer as when they are on the main highroad with Plato's Academy or Medieval Scholasticism or the Charity Schools. Here Prof. Smith speaks from strength. By education he means something both wider and deeper than "the formal school tradition" of a civilization : deeper, because in fact more than half his study of each great age is devoted to its cultural pattern, rooted in its religion, writing-system and habitat; and wider, because his focus is as follows: "Formal education arose initially to supply training for specialists - scribes, priests, accountants. These functionaries arose with the urban revolution, and were indispensable in connection with the administration of the economic surplus" (p. 129; italics mine). This general thesis he sustains in his first chapter, on the "Grand Divisions of Cultural History", which is certainly a fascinating build-up from the Lower Palæolithic families by way of the "Neolithic revolution" into urban centres needing special. ization of function and therefore formal education (the whole transition illustrated archæologically in Mesopotamia).

The great peoples then surveyed are those of Mesopotamia, Ancient Egypt, Ancient India, Ancient China, Greece, Rome and the Hebrews-with a concluding chapter on anthropologically primitive societies to-day as living witnesses of the 'nonliterate' stage. The pace is fast, and the narrative a deft outline. One is not sure whether the book is primarily for the reader knowing nothing of the matter until he comes to it, or the student needing revision and a refresher. Certainly both will find in it plenty of great value. At times there is masterly summarization; as, for example, that on Aristotle : "The forms as such do not change, but matter is constantly taking on new forms; hence the sensible world is perpetually changing, and as it does so new forms are realising their potentialities or purposes". But there is equally too much sheer repetition, and too much of "as X states", or (oftener) "stresses", or (most of all) "aptly puts it". These quirks are the more irritating since the author can be really profound and graceful when he takes the trouble: for example, in explaining how and why the educational contribution of the Greeks towers above that of contemporary teachers in India and China. "The Indians (Aryas), initially a jolly and extroverted people, early fell under the sway of a sacred literature and a tyrannical priesthood. The Chinese escaped the sacred and the priestly, but succumbed to the past. . . . By way of contrast, the Greeks had no sacred book, no priestly hierarchy, and no authoritarian tradition to keep them from speculating about the nature of man and the world. Their geniuses were, therefore, relatively free. . . ."

That is good writing; and in this book by the former professor of education in the University of California, which makes no claim to great originality and is based on a massive bibliography of alreadypublished studies, there is much like it.

\section{A. C. F. Beares}

\section{DEVELOPMENTS IN TECHNICAL EDUCATION}

\section{Technical Education}

Its Aims, Organisation and Future Development. By Dr. P. F. R. Venables, with five chapters by Specialist Authors. Pp. xii +645 . (London : G. Bell and Sons, Ltd., 1955.) 42s. net.

" THOUGH technical education is but a small sector of the whole field of education, it nevertheless has a lasting significance in meeting the economic needs of the country through industry and commerce, and in the importance that work and education for work must always have in the individual lives of innumerable people." In these words, Dr. P. F. R. Venables in his preface succinctly states the case for a wider understanding, on the part of both the public and experts, of this field of education.

It is surprising that during the past twenty-five years only one other major volume has been published on the work of technical colleges; although innumerable reports, journals and conferences have dealt with special aspects of technical education. It is therefore most timely that this very comprehensive and authoritative work should appear in print in the same year as Parliament has sanctioned the creation of a diploma in technology and a national council to control the award of that degree-level qualification.

The whole volume comprises twenty chapters: introduction; the colleges; the courses; co-operative partnerships; liaison with industry; selection and placement; seven specialist chapters on selected industries or studies; higher technological education; finance and administration; students' problems; staffing; buildings; and prospect. There are also copious statistical appendixes, a subject index and a name index. Fach chapter is very fully annotated by references to a bibliography, and there are many diagrams and graphs illustrating the text. 